\title{
Musik Bandar dalam Perspektif Seni Budaya Nusantara
}

\author{
Martarosa $^{1}$ \\ Prodi Seni Musik, Institut Seni Indonesia Padang Panjang
}

\begin{abstract}
ABSTRAK
Musik bandar merupakan salah satu jenis musik yang dikategorikan sebagai hasil dari proses apropriasi musikal, yaitu penyesuaian dan penerimaan antara budaya yang datang dengan budaya lokal. Artikel ini bertujuan untuk memaparkan proses pembentukan musik bandar dalam aspekaspek apropriasi musikal. Penelitian dilakukan dengan pengamatan terhadap berbagai jenis music yang berkembang di pelabuhan di Nusantara. Berdasarkan penelitian disimpulkan bahwa kehadiran musik bandar diwujudkan dari sebuah peradaban pluralistis yaitu, proses penyebaran dan interaksi dari berbagai unsur dapat diterima dan dimasukkan ke dalam proses pembentukan budaya. Jenis musik bandar tersebut meliputi: musik gamat, musik ronggeng, musik ghazal, musik dondang sayang, musik keroncong, dan musik gambang kromong.
\end{abstract}

Kata kunci: musik bandar; apropriasi budaya; seni pesisir

\begin{abstract}
Bandar Music in the Perspective of Nusantara Cultural Arts. Bandar music is a type of music which is categorized as the result of the appropriation of musical process and is the intercultural adjustment and acceptance of the coming culture and the local culture of each region. This article aims to describe the formation process of bandar music in the aspects of musical appropriation. The research was conducted by observing various types of music that were developed in ports of Nusantara. The research result shows that the presence of bandar music is manifested from a pluralistic civilization, i.e. the process of dissemination and interaction of various outside elements which are able to be accepted and included in the process of cultural formation. The types of bandar music such as: gamat, ronggeng, ghazal, dondang sayang, keroncong, and gambang kromong.
\end{abstract}

Keywords: bandar music; cultural appropriation; coastal arts

\section{Pendahuluan}

Tumbuh dan berkembangnya musik bandar di berbagai Pesisir Nusantara sangat dipengaruhi oleh sekelompok orang (masyarakat) pribumi (lokal) melalui ajang kreatifitas baik secara langsung maupun tidak langsung dipengaruhi oleh sekelompok orang pendatang. Sebelumnya, kehadiran seni budaya yang dibawa oleh sekelompok orang pendatang ini dijadikan sebagai ajang apresiasi oleh masyarakat pribumi. Selanjutnya peristiwa ini menjadi motivasi untuk mendorong munculnya kreatifitas oleh sekelompok orang pribumi dalam bentuk apropriasi musikal sebagai perwujudan bentuk musik baru. Dalam waktu singkat, musik ini berkembang menjadi budaya masyarakat pesisir dengan menonjolkan seni musik tradisi 'kelokalannya' di berbagai bandar di Nusantara.

Menurut Schneider (2006: 21) apropriasi berarti "menjadikannya sebagai milik sendiri". Istilah ini merupakan akar dari penerapan secara terus-menerus yang muncul dalam berbagai diskusi oleh para ahli antropologi tentang pengembalian "hak kekayaan budaya" yang dijadikan sebagai implikasi politis dari apropriasi budaya.

\footnotetext{
Alamat korespondensi: Prodi Seni Musik, ISI Padang Panjang. Jln. Bahder Johan, Guguk Malintang, Padang
} Panjang, Sumatra Barat 27118. HP. +628126729103. Email: marta23365rosa@gmail.com. 
Kehadiran musik bandar sebagai seni budaya masyarakat Pesisir Nusantara dapat dikatagorikan sebagai salah satu bentuk apropriasi yaitu, penyesuaian dan penerimaan antara budaya yang datang (objek) dengan budaya lokal masing-masing daerah sebagai penunggu (subjek) yang menjadikannya milik sendiri. Tidak mengherankan bahwa, jenis musik bandar adalah sebuah hasil dari kreatifitas sekelompok orang pribumi yang menonjolkan budaya kelokalannya yang secara tidak langsung dipengaruhi oleh sekelompok orang pendatang dengan berbagai seni budaya yang dibawanya. Hal ini sesuai dengan pernyataan Alexander dan Sharma (2013: 89) yang menyatakan bahwa peningkatan globalisasi dan pergerakan manusia, objek, dan ide menyebabkan hibriditas muncul dan menjadi identitas, baik pribadi atau komunal seperti halnya bahasa, musik, budaya visual/material, budaya pop dan seni. Sementara itu, prinsip hibriditas menurut Mayall (2016: 31) adalah mengombinasikan genre yang mungkin melalui penjajaran dan sintesis dalam komposisi musiknya.

Bandar adalah sebuah tempat berlabuhnya kapal, perahu atau disebut juga sebagai kota pelabuhan atau kota perdagangan di berbagai wilayah Pesisir (KBBI, 2015: 130). Melalui laut, berbagai peradaban dan kebudayaan dari berbagai bangsa, seperti: India, Cina, Arab, dan Eropa masuk ke Indonesia (Asnan, 2007: 3). Tidak mengherankan dengan fase persentuhan yang terjadi dari berbagai peradaban dan kebudayaan luar, baik secara langsung maupun tidak langsung aspek-aspek persentuhan tersebut telah menjadi bagian dari kehidupan mereka sehingga melekat dan dijadikan sebagai budaya masyarakat Bandar, termasuk jenis seni musik yang tumbuh dan berkembang di seluruh wilayah Pesisir Nusantara.

Ditilik dari sudut perspektif modern kelompok etnis (kedaerahan) di Asia Tenggara, telah terdefinisikan bahwa masing-masing etnis yang pluralis itu memunculkan hubungan saling terkait secara longgar melalui perdagangan, hingga kolonialisme serta bangkitnya rasa nasionalisme membentuk peta mutakhir kawasan ini. Berbagai aneka ragam budaya yang terpisah-pisah dan pluralistis tersebut bersemayam suatu prinsip interaksi yang dinamis dalam pergerakan kreasi aktif heterogenitas yang dapat diringkas dalam istilah peradaban pesisir (pasisir) atau peradaban "daerah pantai" (Vickers, 2009:1).

Peradaban pesisir pluralistis yang dimaksud adalah proses penyebaran dan interaksi dari berbagai unsur dapat diterima dan dimasukkan ke dalam proses pembentukan budaya. Dalam artian bahwa peradaban pesisir itu tidak hanya didukung oleh penganut satu agama saja, namun ikut serta dalam proses dan pertunjukan budaya (Vickers, 2009: viii).

Secara musikal dapat diamati bahwa jenis musik bandar sebagai kota pelabuhan di Pesisir Nusantara memiliki bentuk dan struktur musikal relatif sama. Berikut dipaparkan jenis musik bandar yang berkembang sebagai seni budaya masyarakat Pesisir Nusantara meliputi: gamat, ronggeng, ghazal, dondang sayang, keroncong dan gambang kromong.

\section{Musik Gamat}

Musik gamat adalah salah satu bentuk seni pertunjukan musik genre Melayu yang berkembang di daerah Pesisir Sumatera Barat, yang nyanyiannya berbentuk pantun kadang-kadang diselingi dengan gerak tari secara bebas. Awalnya formasi instrumen yang digunakan adalah sejenis instrumen akustik meliputi: biola, akordion, gitar, tambourin, gendang bermuka dua dan vokal (Gambar 1).

Sejak tahun 80an formasi instrumen ini mengalami perubahann yang jumlahnya bertambah dalam bentuk combo band seperti: gitar melodi elektrik, gitar bas elektrik, organ, saxophon dan drum set (Gambar 2).

Seiring berkembangnya teknologi digital, instrumen musik sebagai pengiring lagu daerah seperti keyboard (organ) mampu melahirkan berbagai macam jenis bunyi bagaikan band lengkap (Ardipal, 2015: 17). Hal yang sama juga terjadi pada musik gamat yaitu menggunakan organ melalui program midi mampu melahirkan bunyi sebagai pengganti beberapa instrumen musik seperti: drum-set, bass electric, dan gitar melodi elektrik. Selanjutnya formasi instrumen musik ini ditambah dengan beberapa instrumen akustik seperti: biola, akordion, saxophon, gendang bermuka dua dan vokal (Gambar 3). 
Sungguhpun demikian, ketiga bentuk formasi instrumen musik gamat yang digunakan masih dapat dilestarikan dan dapat dijumpai sampai saat ini (Martarosa, 2017: 251-279).

Proses apropriasi musik gamat terjadi dalam bentuk multikultural secara kompleks dalam perwujudan budaya masyarakat Pesisir Minangkabau Sumatera Barat, sebagai pengaruh dan pewaris budaya dari penjajahan kolonial (Martarosa, 2016: 20). Perbedaan dan kemiripan musik gamat dengan jenis musik bandar yang

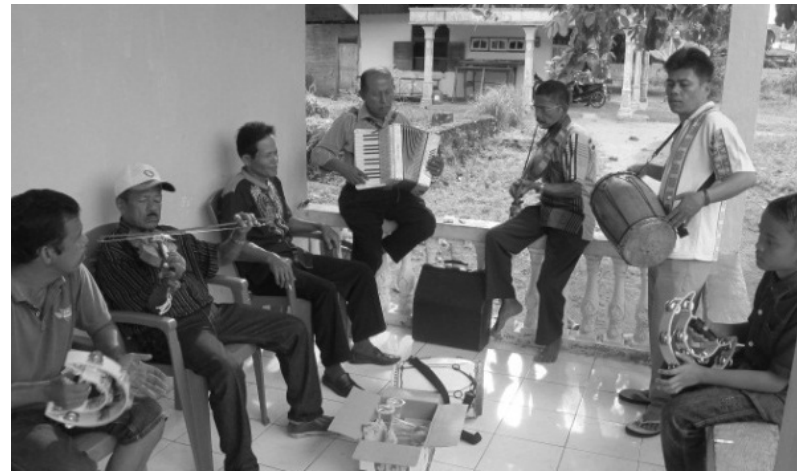

Gambar 1. Suasana latihan kelompok musik gamat Gurindam Pasisie. (Foto: Martarosa, 2016)

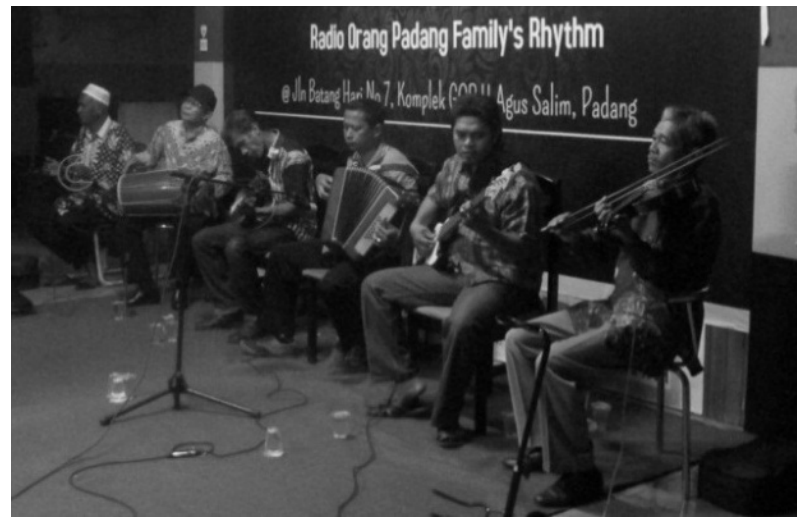

Gambar 2. Formasi instrumen musik gamat kelompok Gurindam Lamo Kota Padang. (Foto: Martarosa, 2015)

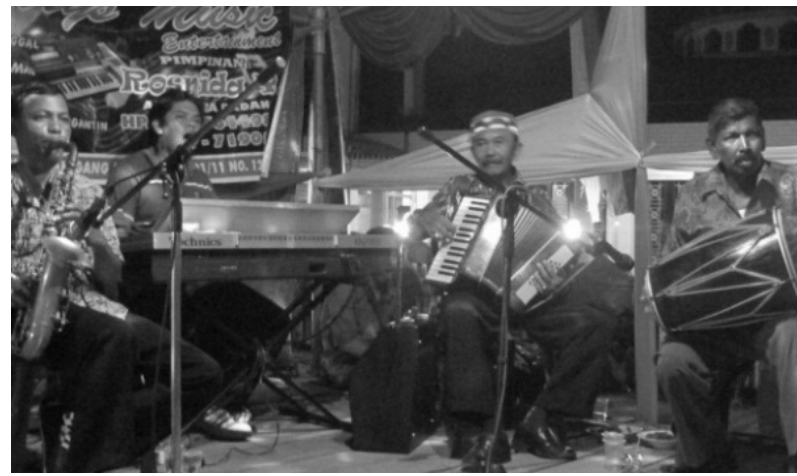

Gambar 3. Formasi instrumen kelompok musik gamat "Lourys Music" Kota Padang di Kec. Kota XI Tarusan. (Foto: Martarosa, 2015) lain, secara musikal dapat dicermati dari lagulagu sebagai materi pertunjukannya. Musik gamat sangat menonjolkan idiom-idiom musik tradisi Pesisir Minangkabau sebagai pengaruh dari budaya lokal. Idiom-idiom musik lokal yang ditonjolkan diduga bersumber dari musik rabab pasisie dalam bentuk bakaba (resitasi) dan dendang pauah. Idiom-idiom musik lokal tersebut diolah dalam bentuk penggarapan melodi baik untuk musik instrumental maupun musik vokal. Untuk musik instrumental teknik permainan disajikan dalam

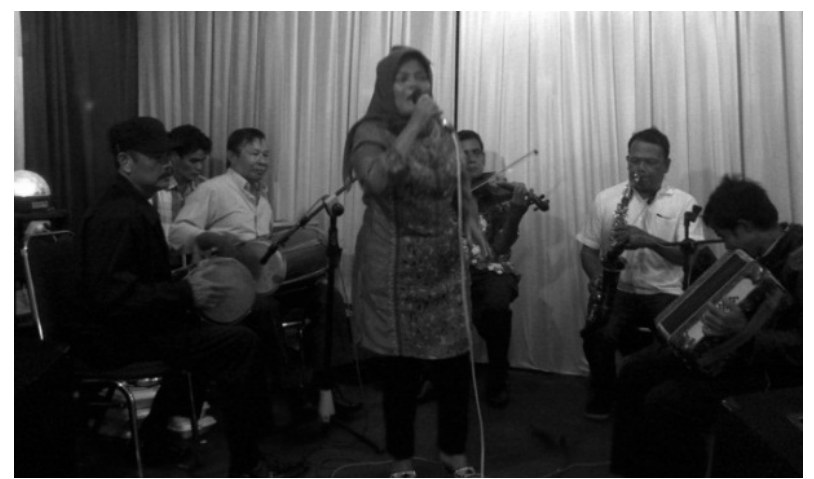

Gambar 4. Penyanyi musik gamat perempuan Linasti asal Minang. (Foto: Martarosa, 2016)

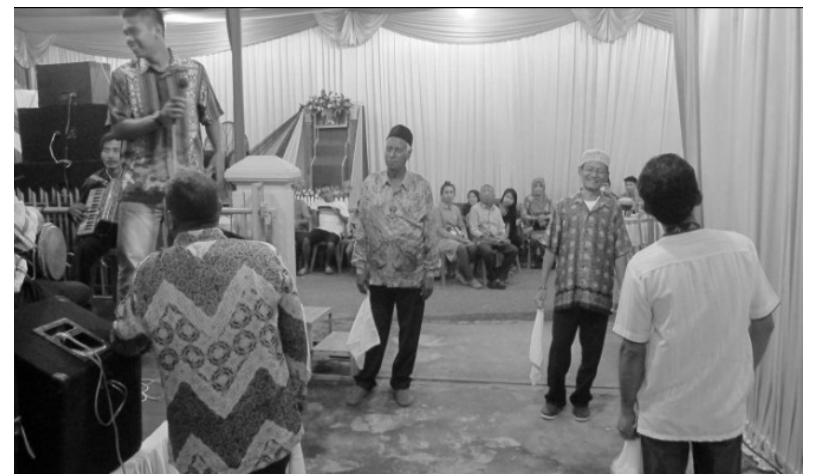

Gambar 5. Susunan penari langgam sekaligus sebagai penyanyi secara bergiliran dengan gerak bebas dalam musik gamat di Berok Kota Padang. (Foto: Martarosa, 2016)

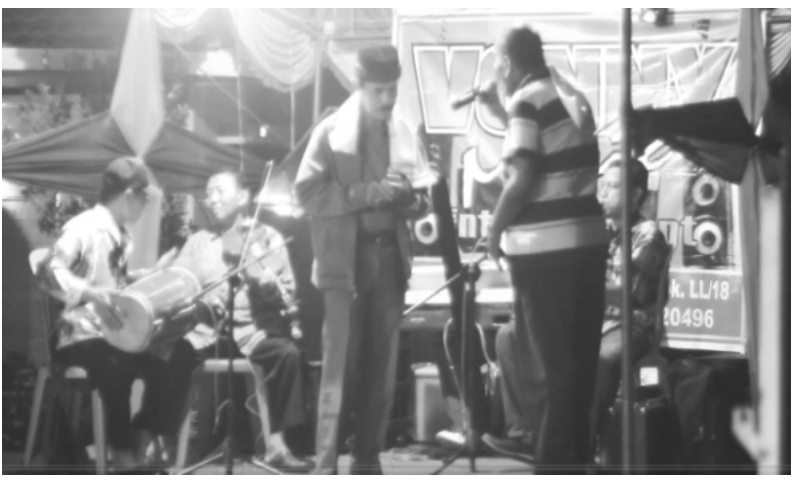

Gambar 6. Dua orang penyanyi musik gamat sedang berbalas pantun Tawanto Karim dan Tembi di Lubuak Bagaluang Padang. (Foto: Martarosa, 2015) 
bentuk melodi disebut garitiak, sedangkan untuk musik vokal disebut gayo. Kedua bentuk teknik permainan melodi tersebut diduga mengandung estetika yang berbeda dengan yang dimiliki oleh musik-musik bandar yang lain, seperti dondang sayang (Malaka), ghazal (Melayu Riau), dan ronggeng (Melayu Deli Sumatera Utara).

Tumbuh dan berkembangnya musik gamat sebagai seni budaya masyarakat bandar di Pesisir Sumatera Barat dan begitu juga dengan jenis musik yang lain, diasumsikan terjadinya apropriasi yaitu penyesuaian dan penerimaan antara budaya yang datang (objek) dengan budaya lokal masing-masing daerah sebagai penunggu yang menjadikannya milik sendiri. Berbagai interaksi yang mempengaruhi tumbuh dan berkembangnya musik gamat meliputi: Portugis, Belanda (Barat), Melayu, dan Minangkabau (Martarosa, 2008: 27-31).

Sebaliknya hal yang sama juga terjadi di masing-masing wilayah tetangga seperti, di Melayu Semenanjung Malaka (musik dondang sayang), di Melayu Kepulauan Riau (musik gazal), dan di Melayu Sumatera Utara (musik ronggeng). Beberapa peneliti yang lain menafsir keserupaan dan perbedaan gejala musik gamat adalah sebagai hasil proses saling mempengaruhi antarbudaya, utamanya wilayah Minangkabau di Sumatera Barat adalah budaya masyarakat Pesisir. Kehadiran instrumen musik Barat (biola, akordion, dan gitar) dalam gejala musik gamat tersebut memunculkan dugaan bahwa salah satu sumber pengaruhnya adalah budaya Eropa yang awalnya diperkenalkan oleh bangsa Portugis melalui pelaut Melayu sebagai kesenian "Bandar."

Franca (1985: 17-18) menjelaskan bahwa, karakteristik Portugis yang melekat dalam musik Ronggeng Melayu di Deli Sumatera Utara sangat tampak jelas adanya pengaruh Portugis dalam musik dan sebagai tari-tarian daerah. Karakteristik Portugis yang ada dalam seni-seni Melayu tersebut Franca katakan sebagai hasil pengaruh tidak langsung yang diberikan di kemudian hari oleh Semenanjung Melayu, bukan pengaruh langsung dari Portugis seperti di Malaka pada abad ke-17. Dalam artian ada pihak lain yang memperkenalkannya kepada penduduk setempat. Pengaruh tidak langsung itu kemungkinan juga terjadi dalam masyarakat bandar di Pesisir Sumatera Barat seperti dikatakan Navis (1984: 276) bahwa, musik gamat yang berkarakteristik Portugis tersebut diperkenalkan oleh para pelaut Melayu yang berlabuh di kota bandar Pesisir Sumatera Barat pada masa lalu.

Dengan demikian perbedaan yang terdapat $\mathrm{di}$ antara jenis musik gamat di masing-masing daerah memunculkan dugaan bahwa tradisi sajian musik gamat yang dipengaruhi Eropa (Portugis, Belanda) tersebut tidak sekadar diterima apa adanya di masing-masing daerah budaya. Perbedaan musikal di masing-masing daerah mengarahkan pada dugaan adanya proses penyesuaian unsur budaya yang diterima dari luar ke dalam budaya lokal masing-masing sehingga dapat dipandang sebagai unsur budaya milik sendiri.

Ditilik secara musikal bahwa musik gamat memiliki satu jalur benang merah dengan bentuk musik sejenisnya seperti: keroncong, gambang kromong, dondang sayang, ronggeng, dan gazal. Dalam penyajiannya jenis musik ini sama-sama menggunakan biola, kecuali musik gambang kromong dengan menggunakan rebab. Kesamaan juga terjadi dalam konteks adanya pengaruh Portugis dan Belanda (Eropa). Hal yang sama juga terlihat dalam bentuk dan struktur lagu yang disajikan, yaitu sama-sama memiliki intro, lagu pokok, interlud, dan coda. Pada setiap bagian kalimat lagu yang dinyanyikan, juga sama-sama memiliki sebuah counter melodi pengantar (Martarosa, 2017: 216-217). Berikut dipaparkan salah satu contoh bentuk syair lagu gamat berjudul: Sarunai Aceh:
Bungolah sarunai manyarunai
Ondeh dunsanak
Bungolah sarunai manyarunai
Ondeh dunsanak
[Bungalah serunai menyerunai
Duhai dunsanak
Bungalah serunai menyerunai
Duhai dunsanak]

Jatuah malah ka lubuak bagalombang
Sarunai Aceh
Jatuah malah ka lubuak bagalombang
Lablamo lah bana kami marasai
Ondeh dunsanak

Jatuah malah ka lubuak bagalombang Sarunai Aceh

Jatuah malah ka lubuak bagalombang

Ondeh dunsanak 
Lahlamo lah bana kami marasai

Ondeh dunsanak

[Jatuh ke lubuk yang bergalombang

Sarunai Aceh

Jatuh ke lubuk yang bergalombang

Sudah lama sekali kami melarat

Duhai sanak keluarga

Sudah lama sekali kami melarat

Duhai sanak keluarga]

Bilo malah masonyo badan kasanang

Sarunai Aceh

Bilo malah masonyo badan kasanang

Ikolah baru gadangnyo badan

Ondeh lah malang

Ikolah baru gadangnyo badan

Ondeh lah malang

[Kapan masanya badan berbahagia

Serunai Aceh

Kapan masanya badan berbahagia

Inilah baru besarnya badan

Duhai sudah melarat

Inilah baru besarnya badan]

Badannyo bajalan nan di gaduang kasam

Sarunainyo Aceh

Badannyo bajalan nan digaduang kasam

Sarunai nyo malang

[Duhai sudah melarat

Bandannya berjalan di gedung Kasam

Serunainya Aceh

Bandannya berjalan di gedung Kasam

serunainya melarat]

Ikonyo baru gadangnyo badan

Ondeh lah malang Sansarolah badan nan

ditangguang

Sarunainyo Aceh

Sansarolah bana yo nan batangguang

Sarunainyo malang

[Ini baru besarnya badan

Duhai sudah melarat sensaralah badan yang

ditanggung)

Serunainya Aceh

Sensaralah benar yang ditanggung

Serunainya melarat]

Sikunalambak biduak tiagan biduak tiagan
Sikunalambak biduak tiagan biduak tiagan

Siapuik malah namo nan kodonyo

Saruani Aceh

Si Apuik banamo nangkodonyo

[Sikulambak samapn tiagan sampan tiagan

Sikulambak samapn tiagan sampan tiagan

Si Apuik sepertinya nama nahkodanya serunai Aceh

Si Apuik sepertinya nama nahkodanya]

Kok kitolah kalah bana untuangnyo badan

Kok kitolah kalah bana untuangnyo badan

Ondeh diak sayang

Disabuik lah apo kagunonyo

Ondeh dunsanak

Disabuik lah apo kagunonyo

[Seandainya kita kalah benar untungnya badan

Seandainya kita kalah benar untungnya

badan

Duhai adek sayang

Disebut apalah gunanya

Duhai sanak kelarga

Disebut apalah gunanya]

Pajalah ketek pandai mambaliak

Ondeh dunsanak

Pajalah ketek pandai mambaliak

Ondeh lah malang

Lah ditimpo lai nan malang

Saruanai nyo malang

Saruanai nyo malang

[Anak kecil pandai membalik

Duhai sanak keluarga

Anak kecil pandai membalik

Duhai sudah melarat

Sudah ditimpa lagi yang malang

serunainya melarat

serunainya melarat]

\section{Musik Ronggeng}

Musik ronggeng adalah sejenis ensambel musik (akustik) di samping nyanyiannya berbentuk pantun sampiran dan isi juga digunakan untuk mengiringi tari dengan melibatkan penari laki- 
laki dan perempuan. Dalam budaya masyarakat Melayu musik ronggeng selalu tampil pada acaraacara seperti resepsi perkawinan, panggung terbuka pesta rakyat (pasar malam), dan acara-acara hiburan lainnya (Musmal, 2010: 81). Genre kesenian ini termasuk salah satu seni pertunjukan hiburan yang melibatkan penonton aktif menari bersama penari ronggeng, yang biasanya dibayar melalui kupon atau tiket dengan harga tertentu. Lazimnya penyanyi ronggeng dalam pertunjukannya selalu berbalas pantun sambil menari bersama mitranya, kemudian disahuti dengan penari laki-laki lainnya secara berpasangan (Gambar 7). Tari dan musik ronggeng termasuk ke dalam tari sosial yang lebih banyak melibatkan perkenalan antara berbagai bangsa. Menariknya kesenian ronggeng juga terdapat unsur berbagai budaya yang mampu mewujudkan sebuah kesatuan melalui seni pertunjukan. Dalam hal ini dapat ditunjukkan dengan tumbuh dan berkembanganya musik ronggeng dengan kuat oleh masyarakat Melayu Sumatera Utara, walau awalnya dipandang rendah (Takari, 2006: 194).

Sinar (1990: 56-66) menjelaskan bahwa beberapa kelompok musik dan tari Melayu adalah termasuk kesenian rakyat (folklore), juga merupakan peralihan antara sesuatu yang tradisional dengan yang modern. Sebagaimana sebelumnya sebagian kesenian tersebut banyak dipengaruhi Islam yang bersifat semireligius, yaitu umumnya syairnya banyak berisikan pemujaan terhadap Allah SWT dan Nabi Muhammad SAW (biasanya dipakai untuk mengiringi ratib). Kelompok ini menjadi kelompok peralihan karena ada beberapa alat musik serta gerak tarinya yang diambil dari Barat (Portugis) dan alat musik asing, seperti biola,

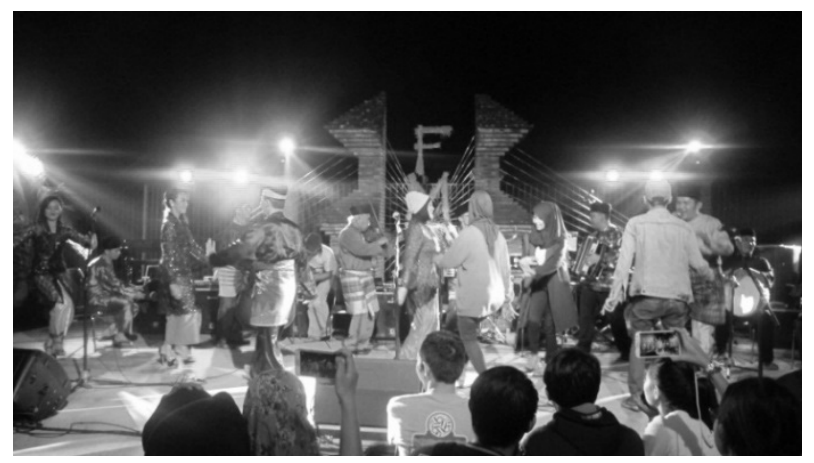

Gambar 7. Seni Pertunjukan musik ronggeng Sumatera Utara dalam bentuk nyanyain dan tari.

(Foto: Martarosa, 2016) akordion, harmonium, dan lain-lain. Namun yang dimaksud dengan adanya unsur pengaruh Portugis tentu bukan saja yang aslinya, tetapi juga pengaruh yang diperoleh dari unsur-unsur Afrika, India, dan lain-lain. Kebanyakan orang Portugis itu datang ke tanah Melayu berasal dari sekitar Lisbon dan provinsi-provinsi di utara, seperti Minho dan Dauro serta kepulauan di Samudera Atlantik: Madeira dan Azores.

Menurut Sinar (1990), kebanyakan lagu-lagu Portugis yang dinyanyikan dan juga musik-musik Melayu yang dimainkan bersifat kegembiraan, halus, dan melankolis dalam skala nada dalam bentuk kunci-kunci minor dan mayor. Bentuk pantun yang dinyanyikan berbentuk pantun kuatrain terbagi dalam pasangan bait, sajak yang dinyanyikan terdiri atas dua baris atau lebih (kuplet). Hal ini terlihat dalam salah satu pantun lagu Melayu, seperti pantun lagu "Makan Sirih" yang mirip dengan pantun nasib lagu "Saudade" dari orang Portugis sebagai berikut.

Makanlah sirih ujung-ujungan

Kuranglah kapur tambahkan ludah

Nasibku ini untung-untungan

Sehari senang sebulan sudah

Nao ha cousa qu mais cheire

Do que a flor da alfazema

Nao ha gooto naste mundo

Que nao renha dar epana

[Tidak ada yang lebih harum

Baunya dari pada bunga lavender

Tidak ada kesenangan di dunia ini

Yang tak berakhir dengan kesakitan]

(Sinar, 1990: 60-66)

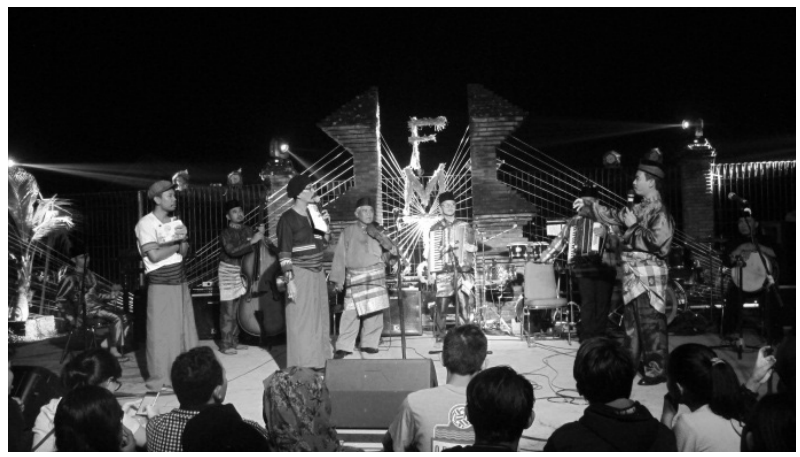

Gambar 8. Pertunjukan musik ronggeng Sumatera Utara dalam persembahan berbalas pantun.

(Foto: Martarosa, 2016) 
Menyanyikan lagu-lagu Melayu menghendaki ciri khas tersendiri (patah dan gerenek). Jenis seperti ini disebut juga "Lagu Berayun" atau "Lagu Berhanyut" karena mengingatkan desau angin laut yang dinyanyikan nelayan tatkala membiarkan sampannya dibawa arus air laut/sungai. Beberapa lagu yang terkenal dalam bentuk jenis tersebut ialah lagu Dondang Sayang (Gunung Sayang), Kuala Deli, Makan Sirih, dan Damak. Untuk pembukaan tari hiburan dalam kesenian, ronggeng biasa dimulai dengan lagu Dondang Sayang disebut "Bismillah Lagu" atau lagu pembuka (Sinar, 1990: 60).

Bentuk pertunjukan seni ronggeng selain menampilkan seni tari, juga menampilkan seni sastra tradisi Melayu dalam bentuk seni berbalas pantun. Selain berbentuk kuatrain, juga disajikan secara melodis dengan menggunakan teknik "strophe" (menyajikan melodi yang sama atau hampir sama dengan teks yang berbeda). Irama atau rentak yang digunakan ada beberapa jenis, meliputi senandung, lagu dua, dan patam-patam. Sebagaimana biasanya rentak dalam lagu-lagu ronggeng dikaitkan dengan permainan pola-pola ritmik yang terdapat dalam gendang ronggeng. Awalnya, bentuk formasi alat-alat musik yang dimainkan terdiri dari biola, gendang ronggeng, dan gong tetawak (Takari dan Dewi, 2008: 184). Selnjutnya music berkembang dengan penambahan harmonium, akordion, dan beberapa alat musik lain, seperti gitar dan contra bass petik.

Secara historis jelas bahwa tumbuh dan berkembangnya musik ronggeng sebagai kesenian Melayu Sumatera Utara tidak luput dari hasil proses akulturasi antara musik Portugis dengan musik Melayu (Takari, 2006: 194). Seiring perjalanan waktu, musik tersebut juga mengalami proses transformasi dari berbagai musik sejenis, seperti musik gambus dan musik ghazal (Musmal, 2010: 81). Dalam artian tumbuh dan berkembangnya musik ronggeng di Sumatera Utara tidak dapat dihindari dari terjadinya proses saling mempengaruhi antarbudaya, seperti Hindu (Karnatak dan Hindustan), Islam (Persia, Arab, dan Gujarat India), Barat (Portugis, Spanyol, Belanda, Inggris), China, dan berbagai suku di sekitarnya (Siam, Aceh, Batak, Minangkabau, dan Jawa) (Hajizar, 2001: .20).
Alat-alat musik yang lazim digunakan dalam ensambel musik ronggeng terdiri dari satu buah biola, satu buah akordion, dan dua buah gendang Melayu (satu buah gendang anak dan satu buah gendang induk). Secara musikal pada dasarnya musik ronggeng merupakan perpaduan cengkok (grenek) Melayu dalam tonalitas diatonis. Grenek dalam ekspresi vokal merupakan kebebasan bernyanyi dalam bentuk improvisasi dan sesuai dengan karakter masing-masing individu para penyanyi (Musmal, 2010: 81).

\section{Musik Ghazal}

Secara umum musik Melayu Riau ditinjau dari unsur-unsur serta variasi-variasi musikal yang menyertainya merupakan adanya pengaruh kebudayaan Arab, Persia, India, dan Barat. Peninggalan budaya tersebut dapat dicermati dengan berkembangnya seni suara yang dikenal dengan berzikir, bersenandung, berdendang, berkaba, berhikayat, bersyair, berpantun, berandai, bergenggong, dan bersuling. Irama dalam nyanyian ini terdiri dari rentak joget, rentak mak inang, rentak Melayu, rentak nobat, rentak ghazal, dan sebagainya. Jenis dan judul lagu yang disajikan terdiri dari Pulut Hitam, Tudung Periuk, Dondang Sayang, Cik Siti, Lancang Kuning, dan sebagainya. Sebagai pertanda adanya pengaruh Barat (Portugis), terlihat dari berbagai jenis musik Melayu yang disajikannya, selalu ada ditemukan penggunaan alat musik biola dalam pertunjukannya (DP\&K, 1982: 177-178).

Hamid (1991: 164), sebagaimana juga dikutip oleh Asri (2015: 115) menulis bahwa ghazal adalah sejenis puisi Arab yang berisikan

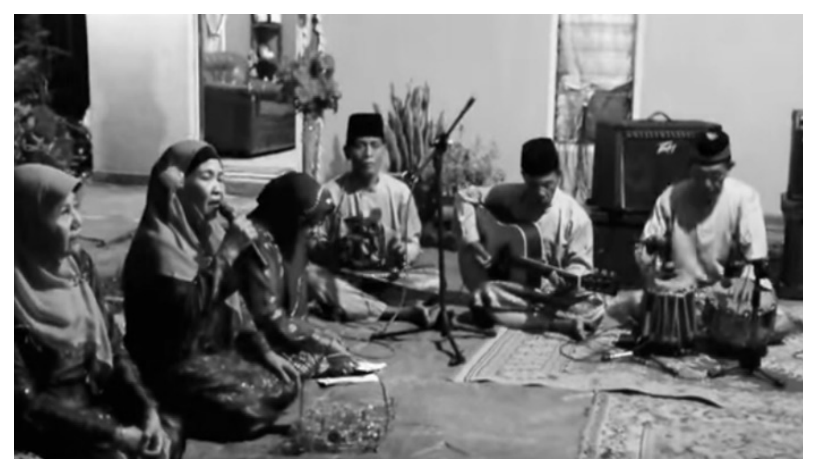

Gambar 9. Pertunjukan Musik Ghazal. (Foto repro dari video: Grup Musik Ghazal "Dendang Serumpun”, https://www.youtube.com/watch?v=dm338qB96PY) 
kisah-kisah percintaan. Begitu kuatnya pengaruh Persia dan Romawi, maka pada zaman Umaiyah, ghazal ini berkembang dari bentuk puisi menjadi nyanyian-nyanyian serta ditambah dengan musik pengiring. Tokoh ghazal yang terkenal pada masa itu bernama Umar bin Ruba'ah. Sebelumnya, di samping nyanyian-nyanyian ghazal ini berkembang di Persia dan India, dari India ini pulalah nyanyiannyanyian ghazal dibawa ke alam Melayu dan diterima sebagai salah satu rentak lagu-lagu asli dalam budaya masyarakat Melayu.

Rohaya (2016), seorang pecinta seni ghazal Melayu Johor Malaysia, mengungkapkan bahwa kesenian ghazal berasal dari tanah Arab yang disebut musik "gamat" yang artinya riuh-rendah. Pada akhir abad ke-19 Kerajaan Johor sudah mulai menjalin hubungan erat dengan Kerajaan Riau Lingga. Beberapa orang dari golongan bangsawan tersebut sering berulang-alik ke Riau Lingga. Oleh karena beberapa di antara mereka di Riau Lingga sudah mendahului mempelajari alat-alat musik ghazal, para pengunjung yang datang dari Johor tersebut sering disuguhkan dengan musik tersebut sebagai hiburannya. Tidak lama kemudian musik ini juga diperkenalkan oleh pemusik Riau Lingga kepada pembesar-pembesar Istana Sultan Johor yang ketika itu berada di Teluk Belanga, Singapura. Pada akhirnya kesenian ini mendapat perhatian pula dari Sultan Johor sehingga menjadi budaya di istana dan berkembang pula di kalangan rakyat jelata dengan cepat dan pesat.

Meskipun pada saat ini musik ghazal Melayu lebih dikenal sebagai musik ghazal Johor, perlu diketahui bahwa irama ghazal mulanya berkembang di istana-istana Riau-Lingga. Adapun beberapa alat musik yang digunakan terdiri dari harmonium, satu set tabla, gambus, violin, gitar, maracas, dan tamborin (Laman Resmi Jabatan Kebudayaan Kesenian Malaysia, 2010). Pertunjukan musik ghazal ini di samping disajikan di istana juga dimainkan di rumah-rumah penghulu pada harihari keramaian tertentu (Rohaya, 2010).

Perkembangan seni musik ghazal di Negeri Johor sering dikaitkan dengan nama Allahyarham Datuak Bentara Luar dan Mohd. Salleh Bin Perang. Pada saat membuka daerah-daerah baru di Johor, Datuk Bentara turut juga memperkenalkan seni musik ghazal kepada masyarakat setempat. Begitu juga para pembesar lain turut memperkenalkan musik tersebut, seperti Ungku Ahmad Bin Mohd. Khalid (Ungku Chik), Ungku Muhammed Bin Mohd Khalid, Ungku Sulaiman Bin Daud, dan Ungku Abdul Aziz Bin Abdul Majid. Tidak kalah menarik juga adalah dengan munculnya Haji Musa Bin Yusof, yang lebih dikenal dipanggil dengan Pak Lomak.

Pak Lomak adalah cucu dari Datok Bentara Luar, juga dikenal sebagai seorang yang mencintai seni musik ghazal. Pak Lomak dikenal sebagai Bapak ghazal kesenian Melayu Johor. Pada masanya, beliau di samping terkenal sebagai pemain alat musik harmonium juga sangat pandai bernyanyi lagu-lagu ghazal. Ia bernyanyi dalam bahasa Urdu, yaitu bahasa resmi orang-orang kawasan Timur India. Berhubung bahasa Urdu kurang populer dalam masyarakat Melayu Johor, mulailah Pak Lomak menerjemahkan lagu-lagu ghazal dari bahasa Urdu ke bahasa Melayu. Pada saat itu pulalah musik ghazal mulai berkembang dalam masyarakat Melayu Johor. Lagu ciptaannya yang terkenal sampai saat ini adalah Sri Mersing. Lagu ini pertama kali dinyanyikan pada tahun $1925 \mathrm{di}$ Singapura. Lagu ini diciptakan sebagai kenangan ketika tinggal di daerah Mersing selama satu tahun (1923-1924) (Rohaya, 2016).

Musik ghazal Melayu Johor terus berkembang dengan beberapa perubahan yang dilakukan seperti penambahan alat-alat musik serta banyaknya penyanyi baru yang muncul dari hasil didikan Pak Lomak. Lagu-lagu baru sudah banyak bermunculan pada tahun 30-an, dan pengaruh India sudah mulai berkurang, kecuali penggunaan alat musik seperti harmonium dan tabla tetap dimainkan. Begitu juga lagu-lagu yang biasa dinyanyikan hanya tinggal beberapa lagu tertentu saja yang masih ada pengaruh unsur India. Musik ghazal Melayu Johor terus diminati oleh masyarakat pecintanya hingga tahun 60-an dan berkembang sampai ke Singapura. Tidak hanya itu, beberapa grup ghazal juga banyak bermunculan termasuk penyanyipenyanyi terkenal, seperti Ahmad Jusoh, Hamzah Dolmat, Rosian Chik, dan Kamariah Noor. Pak Lomak meninggal tahun 1960. Sebagai tanda jasa dan sumbangannya dalam mengembangkan musik 
ghazal, sejak tahun 1998 pemerintah Kerajaan Negeri Johor Darul Ta'zim melalui Yayasan Warisan Johor mewujudkan piala Pak Lomak sebagai piala bergilir dalam ajang pertandingan musik ghazal (Rohaya, 2016).

Asri (2015: 104) menjelaskan bahwa musik Ghazal Melayu yang bergaya Hindustan itu juga disebut musik gamat. Adapun alat musik yang dipakai terdiri dari syarenggi, sitar, harmonium, dan tabla. Awalnya orang Melayu tertarik dengan musik ini karena adanya syair-syair lagu yang berhubungan dengan unsur keagamaan yang isinya memuji kebesaran Nabi Muhammad dan nasihatnasihat.

Pada saat ini musik ghazal di daerah Kepulauan Riau mengalami perubahan bentuk menjadi musik populer. Proses ini terjadi dengan cara menggantikan alat musik Hindustan yang awalnya dimainkan melalui alat musik syarenggi dan sitar, diganti dengan biola dan gambus. Alat musik yang lain seperti harmonium dan tabla tetap bertahan bahkan ditambahkan dengan gitar. Kemauan untuk melakukan perubahan tersebut muncul dari para pelaku seni Istana Raja masyarakat Melayu Riau, baik pada tingkat kabupaten kota maupun tingkat desa termasuk para pelaku seni Pulau Penyengat. Dalam bentuk kreativitas yang lain, sebagaimana materi sajian musik Melayu ghazal yang biasanya hanya memainkan lagu-lagu Melayu asli saja, sekarang lagu-lagu tersebut sudah mulai diaransemen dalam bentuk baru, termasuk berbagai lagu rakyat yang selama ini belum dijadikan materi dalam iringan musik tersebut (Asri, 2015: 105).

Musmal (2010:2) menjelaskan bahwa musik ghazal adalah sejenis musik yang mengiringi nyanyian-nyanyian sebagai melodi pokok utama vokal, berbentuk pantun yang terdiri dari sampiran dan isi dengan ciri temanya bernuansa cinta kasih (love song). Instrumen musik tersebut terdiri dari biola, harmonium, gambus, gitar akustik, tabla, gendang Melayu, dan vokal sebagai pembawa melodi utama.

\section{Musik Dondang Sayang}

Musik Dondang Sayang adalah bentuk nyanyian berbalas pantun yang tidak pernah dilupakan oleh masyarakat Malaka. Musik Dondang Sayang merupakan musik kebanggaan masyarakat Malaka, selalu disajikan dalam acara-acara seremonial adat masyarakatnya, termasuk dalam memperkenalkan Malaka sebagai kota bandar yang bersejarah kepada masyarakat yang datang mengunjunginya. Begitu juga dengan nyanyian joget lambak yang disajikannya, kedua jenis musik ini hubungannya sangat kuat, seperti kapur dengan sirih yang sudah lama menjadi budaya masyarakat Malaka (Usop, 2000: 8). Kedua jenis musik ini tidak dapat dipisahkan, sebagaimana lazimnya bentuk irama musik Melayu yang selalu disajikan bercirikan langgam dan joget.

Dondang Sayang juga disebut sebuah nyanyian perantaraan (pembuka), di mana bentuk pertunjukannya diiringi oleh permainan alat-alat musik Melayu asli dan modern. Nyanyian Dondang Sayang akan didengar dengan penuh minat oleh penikmatnya, tentu tidak luput dari kemampuan atau kebolehan serta kecakapan para penyanyinya dalam berpantun spontan dalam suasana pertunjukan yang sedang berlangsung. Alat-alat musik yang mengiringi nyanyian Dondang Sayang terdiri dari sebuah biola, sebuah gong, dan dua atau tiga buah rebana, yaitu rebana kompang atau rebana keras. Beberapa irama yang disajikan melalui gesekan biola dapat dianggap sebagai pembuka dan pengiring utama lagu atau nyanyian. Sementara tingkah pukulan rebana yang diselingi dengan pukulan gong merupakan variasi musik iringan dalam menentukan aksentuasi dalam berbagai jenis tempo irama lagu yang akan dimainkan (Laman Resmi Jabatan Kebudayaan Kesenian Malaysia, 19 April 2016).

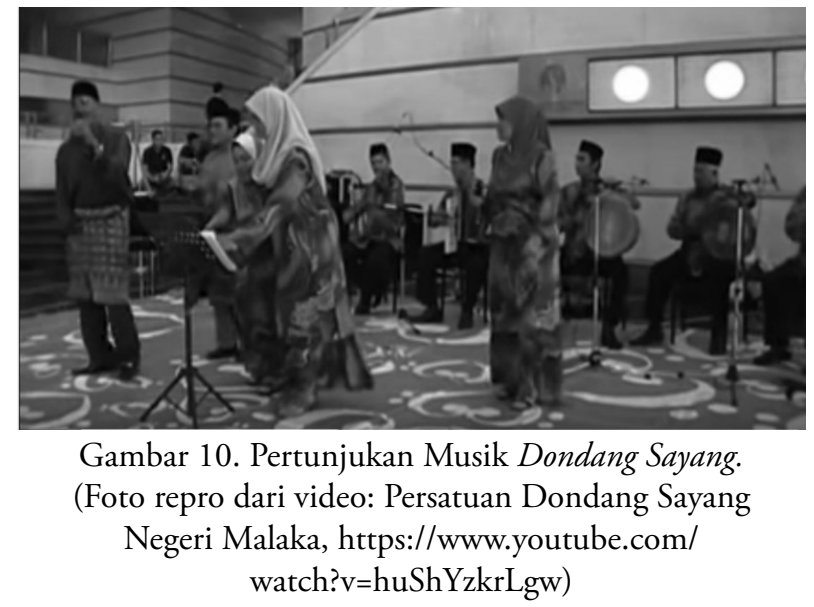


Berikut salah satu contoh pantun Dondang Sayang yang dinyanyikan oleh ibu-ibu di Malaka ketika menidurkan anak-anak mereka.

Kalau nak gugur gugurlah nangka

Jangan terhempas si putik pauh;

Kalau nak tidur tidurlah mata,

Jangan dikenang orang yang jauh.

Sorong papan tarik papan

Buah kuranji dalam perahu;

Suruh makan engkau makan

Suruh mengaji engkau tak tahu.

Rumah keci tiang seribu

Rumah besar tiang sebatang;

Masa kecil ditimang ibu

Sudah besar ditimang gelombang

(Usop, 2000: 9-10).

Jelaslah bahwa lagu dan pantun itu sudah didendangkan kepada anak-anak sejak kecil bahkan dari bayi. Pantun yang dinyanyikan itu sudah merupakan pembentukan jiwa dan akhlak semenjak kecil. Msyarakat Melayu Melaka begitu fanatik dengan Dondang Sayang, dari golongan apa pun baik anak-anak maupun orang dewasa, baik masyarakat bandar maupun desa, baik golongan orang berada maupun orang biasa di Malaka penduduknya boleh menyanyikan patun dan mengetahui melodi dan iramanya, sungguhpun mereka tidak terlalu pandai bernyanyi (Usop, 2000: 9).

Musik Dondang Sayang dipercayai muncul di Malaka pada zaman Kesultanan Melayu Malaka pada kurun abad ke-15 Masehi. Musik ini sudah membudaya dalam masyarakat Melayu lebih kurang 500 tahun lamanya. Jarak waktu yang sekian lama itu, dari berbagai hal yang telah dilalui, wajar jika perkembangan yang terjadi sepanjang usianya menjadikannya mempunyai nilai-nilai keklasikan. Musik ini sangat dinamis dan liberal, masyarakat dan para pelaku seninya siap menerima perubahan yang mempengaruhinya sepanjang tidak bertentangan dengan bentuk-bentuk lagulagu Melayu asli yang telah mentradisi sebelumnya. Musik ini tidak saja mampu menerima nyanyian yang berubah dari gaya asalnya, malah boleh diubah sesuai dengan gaya pertunjukannya. Termasuk perkembangan alat-alat musik dan bentuk-bentuk irama atau rentak-rentak yang lain yang mampu mengubah suasana pertunjukan Dodang Sayang, seperti rentak ghazal cepat, rentak inang, dan rentak zapin (Usop, 2000: 12). Penambahan alat musik pada Dondang Sayang merupakan sebuah simbolis yang mencernakan satu sejarah kegemilangan Negeri Malaka pada masa dahulu.

\section{Musik Keroncong}

Musik keroncong adalah sebuah ensambel musik kota bandar dengan ciri musikal yang unik dalam menonjolkan permainan alat musik ukulele, secara seksional terdiri dari cak dan cuk. Menurut Ganap (2006), tumbuh dan berkembangnya musik keroncong di tanah air tidak dapat dihindari dari pengaruh musik Portugis yang dimulai semenjak abad ke-16. Musik tersebut masih melekat hingga kini ditandai dengan penggunaan waditra ukulele dan ekspresi vokalis. Musik keroncong juga dikatakan sebuah musikal hibrid, sebuah genre musikal dari hasil akumulasi berbagai elemen musikal Barat (Portugis dan Belanda) dan nonBarat (Arab, Afrika, India, China, Occaniasa, Betawi, dan Jawa).

Ernst Heins menegaskan bahwa terjadinya pengaruh berbagai elemen musikal dalam musik keroncong dari berbagai bangsa juga didorong oleh kedatangan kapal Portugis ke Nusantara. Kapal-kapal tersebut tidak hanya membawa Portugis Kulit Putih, tetapi juga diikuti oleh ras lain, seperti Afrika, India, Ceylon, dan Melayu. Awalnya mereka diambil sebagai budak, tetapi lama-kelamaan menjadi keluarga dalam berumah tangga. Mereka menetap di lingkungan berbagai pos perdagangan tempat mereka mendirikan keluarga baru. Mereka menjadi dikenal sebagai Merdeques, Mardicas yang kemudian berubah menjadi Mardykers Belanda, yaitu sebuah istilah yang berasal dari bahasa Sanskerta (mahardika) (Heins, 1975: 21-22).

Meskipun masyarakat Portugis bermukim di Tugu Jakarta, mereka tidak dapat cukup bukti mengklaim sepenuhnya sekelompok 
dengan keturunan Eropa Portugis. Setidaknya dapat dikatakan bahwa nenek moyang mereka adalah budak layanan Portugis dalam waktu yang relatif tidak lama karena digantikan oleh penjajah Belanda. Hal ini ditandai dengan adanya pemukiman Mardika, yang sampai saat ini masih dikenal di Ambon (Maluku) dan Tugu (sebuah desa pesisir di timur laut Jakarta). Secara musikal orang berdarah Portugis dari Tugu-Mardika itu sangat ditunjukkan dalam musik mereka, yaitu musik keroncong yang sampai sekarang masih disajikan oleh penduduk keturunan Mardyker asli. Sudah tertanam bagi mereka dengan bermain musik keroncong singer, sudah berarti mereka melakukan berbagai pertemuan sosial termasuk agama, bahasa, dan musik. Sudah menjadi tradisi dan kebanggaan bagi mereka dengan melakukan pertunjukan musik keroncong singer yang disajikan pada malam hari dan berkumpul di teras depan salah satu rumah milik mereka (Heins, 1975: 22).

Secara musikal cikal bakal tumbuhnya musik keroncong adalah berasal dari sejenis musik Portugis yang dikenal dengan nyanyian fado. Fado adalah lagu rakyat Portugis dengan sistem nada-nada Arab dengan kecenderungan memakai tangga nada minor. Nuansa tangga nada minor yang diperolehnya juga dipengaruhi oleh orang-orang Moor Arab yang pernah menjajah Portugis/Spanyol kurun 711 - 1492. Genre musik ini diperkenalkan oleh para pelaut dan budak kapal niaga bangsa Portugis ke Nusantara sejak abad ke-16. Mereka dari daratan India (Goa) menuju Malaka. Seiring perjalanan waktu, musik tersebut berkembang kali pertama di Malaka dan kemudian juga dimainkan oleh para budak dari Maluku. Bentuk awal musik ini disebut moresco, yaitu sebuah tarian asal Spanyol, seperti polka namun agak sedikit lambat

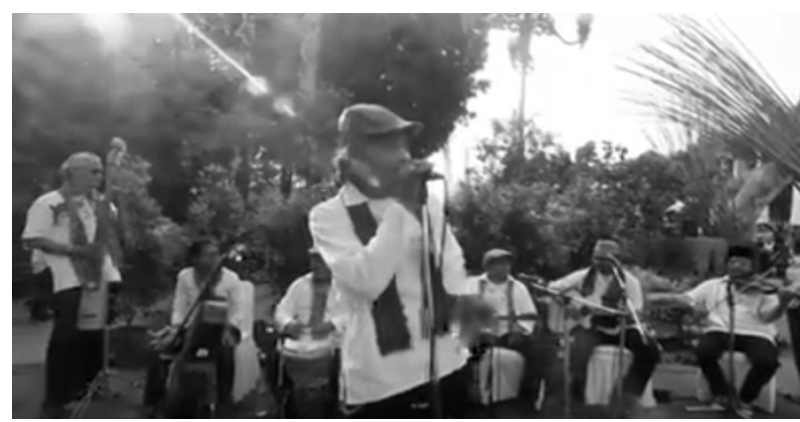

Gambar 11. Pertunjukan Musik Keroncong Tugu. (https://www.youtube.com/watch?v=qci3HE75NLs) ritmenya. Bentuk lagu tersebut disusun kembali oleh Kusbini dan dikenal dengan nama Keroncong Moresco (Destiana, 2012: 154).

Secara historis, beberapa peneliti menafsirkan bahwa musik Kerocong Tugu termasuk salah satu seni musik tradisi Betawi (Jakarta) yang mengesankan dan memiliki unsur irama musik yang kuat pengaruh Portugisnya. Pengaruh tersebut diperoleh dan dibawa oleh orang-orang yang kini merupakan penduduk Tugu keturunan Portugis. Orang-orang tersebut merupakan tawanan-tawanan perang dari daerah-daerah yang diduduki Portugis pada masa lalu, seperti Goa, Malabar, Coromandel, Bengal, Arakan, Malaka, dan sebagainya (Arumsari, 2012: 185).

Pada abad ke-17 unsur-unsur musik Portugis itu dibawa dari Pulau Bandar ke kampung Tugu Jakarta dan berkembang melahirkan musik keroncong. Pengaruh Belanda selama tiga abad menyebabkan repertoar keroncong berbahasa Portugis Cristao lenyap, digantikan dengan repertoar Hindia Belanda dalam bentuk langgam. Pengaruh Jawa pada abad ke-20 melahirkan beberpa bentuk meliputi: keroncong asli, langgam Melayu dan Jawa. Pengaruh komedi bangsawan melahirkan bentuk stambul sebagai antr'acte instrumental yang menjembatani adegan demi adegan. Dalam berbagai ragam bentuk musik keroncong saat ini, pengaruh musik Portugis abad ke-16 dalam bentuk Moresco dapat dikatakan hanya merupakan sebuah mitos, yang di Portugal saat ini juga sudah tidak ditemukan lagi (Ganap, 2006).

Di wilayah Tugu Jakarta sudah sejak lama, hampir tiga setengah abad lamanya, orang-orang keturunan Portugis bercampur dan bersosialisasi dengan suku bangsa lain dan pribumi, seperti Belanda, Tionghoa, dan Sunda. Keturunan mereka

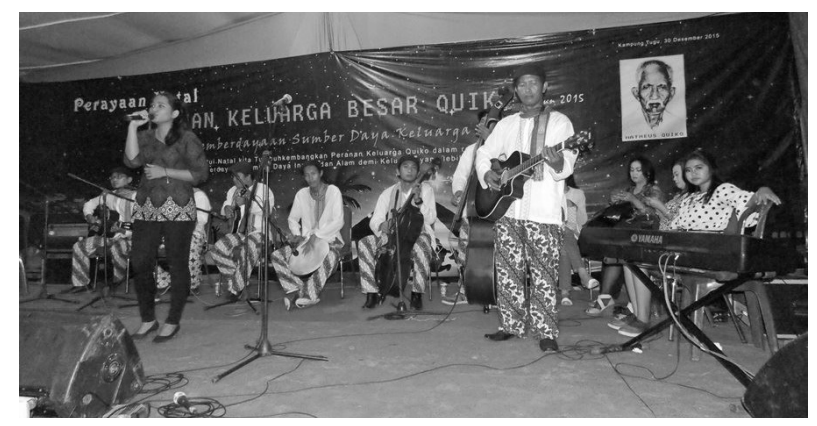

Gambar 12. Pertunjukan Grup "Keroncong Cafrinho". (Dokumentasi: Grup "Keroncong Cafrinho" Jakarta) 
disebut orang "Mestizo". Di Tugu, tempat orangorang tersebut bermukim, lahirlah musik keroncong yang kemudian dikenal dengan Keroncong Tugu. Keroncong Tugu yang awalnya bersifat hiburan semata, mulai terorganisasi dengan baik terhitung sejak dibentuknya Orkes Krontjong Poesaka Moresco Toegoe pada tahun 1920. Orkes ini bubar pada masa pendudukan Jepang akibat pelarangan Jepang yang menganggap irama musik keroncong tugu yang indah (cepat dan bersemangat), dapat membangkitkan semangat pemuda dan memicu pemberontakan. Namun, kondisi yang demikian relatif berlangsung tidak lama. Kelompok-kelompok musik tersebut dibentuk kembali setelah masa penjajahan Jepang berakhir. Mereka menamainya sebagai kelompok keroncong penerus, yaitu Krontjong Toegoe dan Keroncong Tugu Cafrinho. Perbedaan kedua kelompok ini hanya terletak pada keluarga yang menjadi pimpinan kelompoknya. Krontjong Toegoe dipimpin oleh keluarga Michiels, sedangkan Krotjong Toegoe Caprinho dipimpin oleh keluarga Quiko. Pada masa ini penyebutan Krontjong Toegoe dan Keroncong Tugu Caprinho disamakan menjadi Keroncong Tugu saja. Kenyataannya sampai saat ini, kedua kelompok tersebut berjalan beriringan dalam melestarikan musik Keroncong Tugu di Indonesia (Arumsari, 2012: 186-187).

Dengan demikian, keberadaan genre musik tersebut sebagai musik bandar dapat memicu tumbuh dan berkembangnya berbagai kelompok musik keroncong di tanah air, seperti: musik Keroncong Tugu (Betawi Jakarta), musik Keroncong Yogyakarta, musik Keroncong Semarang, musik Keroncong Solo (Surakarta), musik Keroncong Surabaya, musik Langgam Keroncong Bentara (Bali), musik Keroncong Banjarmasin, musik Keroncong Makasar, dan musik Keroncong Ambon, Ternate di Maluku. Dari pengamatan penulis, beberapa kelompok musik keroncong juga tumbuh dan berkembang sampai ke Pulau Sumatera, meliputi Aceh, Medan, Padang dan Palembang. Secara umum genre musik tersebut juga populer pada masa lalu, sungguhpun sekarang sedikit kurang diminati oleh para anak muda. Namun, di luar Tugu Jakarta secara musikal jenis musik genre ini banyak dipengaruhi pula oleh musik-musik tradisi di masing-masing wilayah budaya tempatan dengan menonjolkan kelokalannya (misalnya: di beberapa wilayah di Jawa pada umumnya banyak dipengaruhi oleh musik tradisi gamelan).

\section{Musik Gambang Kromong}

Musik gambang kromong adalah termasuk salah satu seni pertunjukan masyarakat Betawi yang sampai saat ini masih terus dilestarikan. Musik ini sering disajikan dalam acara-acara resmi dan pesta rakyat. Menurut Ganap (2012: 164), pada tahun 1880 kesenian ini sudah diperkenalkan kepada masyarakat lokal dalam bentuk acara seremonial sebagai musik penanti tamu kehormatan oleh seorang tokoh China yang bernama Bek (Lurah), di daerah Senen bernama Teng Tjoe.

Sukotjo (2012: 2) menjelaskan bahwa tumbuh dan berkembangnya musik gambang kromong dalam masyarakat Betawi juga tidak luput ditopang dari berbagai proses interaksi yang terjadi dalam bentuk akulturasi dengan budaya yang datang. Hal ini dapat ditandai dan ditemui dari berbagai alat musik yang digunakan dalam ensambel tersebut, seperti: (1) alat musik gesek dan tiup dari China dan (2) alat musik perkusi, gendang dari Sunda, gambang, kromong, kempul, kecrek, serta gong dari Jawa. Ensambel musik gambang kromong ini terdiri dari berbagai alat musik, meliputi gambang, kromong, sukong, tehyan, kongahyan, basing/suling, ningnong, jutao, kecrek, kempul, dan gong. Bentuk-bentuk perpaduan atas kesenian ini dipergunakan sebagai sarana berintegrasi oleh masyarakat Tionghoa khususnya kelas menengah ke bawah agar dapat diterima oleh masyarakat setempat (Rokhani, 2015: 145).

Para pemain dan penonton kesenian gambang kromong adalah penduduk masyarakat pinggiran Jakarta seperti Bekasi dan Tangerang (Yampolsky, 1990: 1). Mereka terdiri dari dua kelompok masyarakat, yaitu peranakan China dan pribumi Betawi. Masyarakat peranakan China adalah kelompok masyarakat yang berdomisili di Jakarta dan sudah sejak lama menjadi bagian dari penduduk Jakarta. Kelompok ini dinamakan orang China Benteng. Masyarakat ini mempunyai mata pencaharian sebagai pedagang dan memiliki tingkat kehidupan yang baik sehingga dapat memenuhi 
kebutuhan hidupnya dengan layak. Sebagian besar orang China Benteng tinggal di dekat pusat kota dan memiliki taraf kehidupan yang baik sehingga kerapkali mempergunakan musik gambang kromong untuk menghibur para tamunya (Sukotjo, 2012: 3).

Selain kelompok masyarakat asli Betawi, juga ada kelompok masyarakat yang disebut sebagai imigran campuran, yaitu masyarakat yang datang dari berbagai daerah di Indonesia. Selama periode kolonial, mereka dibawa sebagai budak ke Jakarta sehingga dari waktu ke waktu kehilangan hubungan ke tanah air mereka. Kelompok masyarakat pribumi tersebut hidup di lingkungan yang sama atau saling berdekatan dan berbicara dengan menggunakan dialek Betawi sebagai bahasa utamanya. Pada masa-masa tersebut sebagian besar taraf hidup mereka masih termasuk dalam tingkat ekonomi yang relatif rendah. Mereka bekerja sebagai nelayan, pedagang asongan, pekerja pabrik, buruh, driver opelet, dan sebagainya (Yampolsky: 1990: 1). Kepemilikan musik gambang kromong dalam masyarakat China Benteng memberikan warna baru sebagai budaya masyarakat Betawi. Proses awal ketertarikan masyarakat Betawi dengan musik gambang kromong adalah dengan masuknya lagu phobin dan alat-alat musik dalam sentuhan sajiannya. Proses demikian memberikan nuansa tersendiri oleh masyarakatnya sehingga orangorang Betawi sebagai pemain gambang kromong mulai tertarik dan mengembangkannya. Begitu juga dengan kelestarian musik tersebut, untuk pembinaan sebagai pemain musik gambang kromong untuk regenerasi penerus dapat dilakukan dengan cara transmisi dari para pemain musik senior yang berpengalaman kepada para pemain musik yang baru. Kesenian tersebut menjadi identitas genre musik masyarakat Betawi sampai saat ini (Sukotjo, 2012: 3).

Pada akhir tahun 1960-an muncullah gambang kromong modern atau disebut juga dengan gambang kromong pop yang dirintis oleh Benyamin Sueb., penyanyi asli Betawi yang kemudian terkenal sebagai aktor film sepanjang akhir hayatnya. Kebanyakan syair lagu yang dinyanyikan bernuansa gembira (riang jenaka), humor, sindiran, sehingga memunculkan warna baru yang kadang-kadang dalam sajian lagunya seakan-akan dialog yang dinyanyikan dalam dialek Betawi. Warna baru musik gambang kromong seperti ini juga dipergelarkan dalam acara pernikahan pengantin sebelum dilakukan seni tari dan sebagainya. Begitu juga dengan berbagai upacara atau bentuk-bentuk perayaan masyarakat Betawi dalam bentuk teater lenong. Sebelum teater lenong dimulai, sebagai acara pembuka juga diawali dengan musik gambang kromomg dengan menyajikan lagu-lagu lain, seperti pop, dangdut, dan sejenisnya (Yampolsky: 1990: 2).

Adapun perkembangan alat-alat musik ensambel gambang kromong modern yang digunakan pada saat ini di samping adanya campuran alat-alat musik dari China dan Indonesia, juga menggunakan alat-alat musik Eropa, seperti gitar melodi elektrik, gitar bass elektrik, gitar Hawaii, keyboard, dan beberapa alat musik tiup, seperti terompet, klarinet, dan saxaphone. Termasuk xylophone (gambang) terdiri dari 18 bilah, sistem

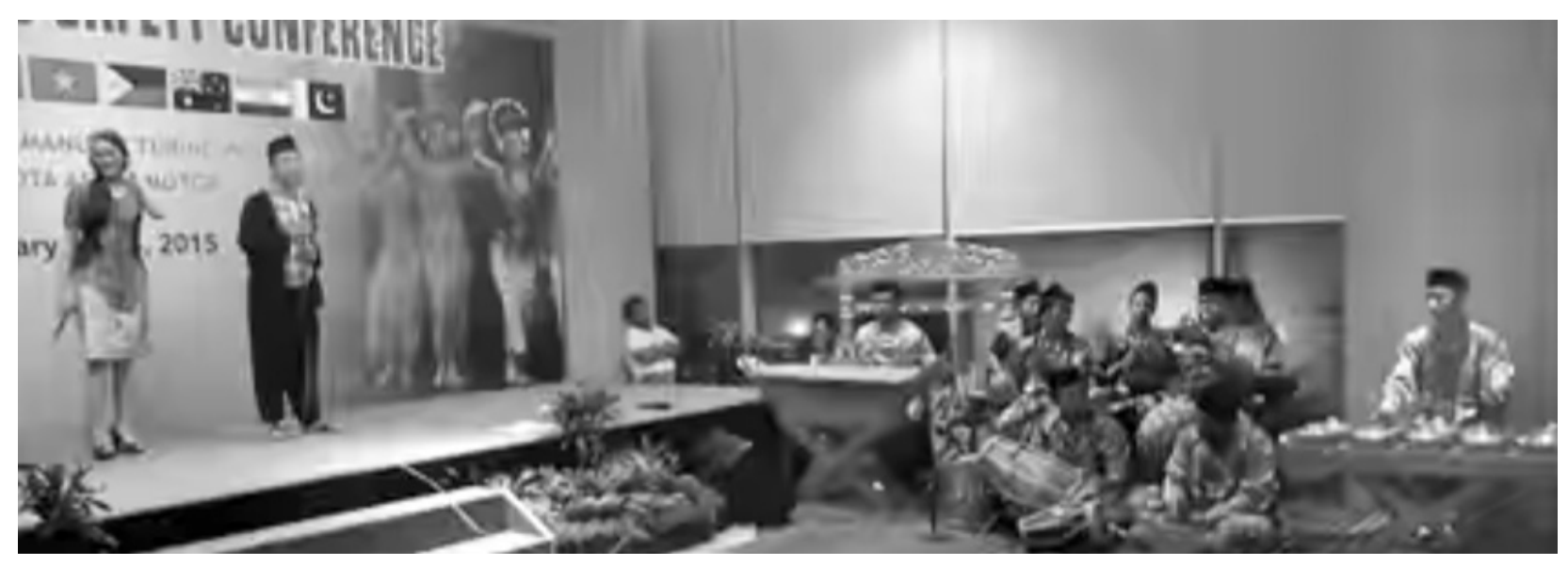

Gambar 13. Pertunjukan Musik Gambang Kromong. (https://www.youtube.com/watch?v=Y-L9du9lguE) 
laras pentatonik, dengan wilayah nada 3 1/2 oktaf, dan 10 set ketel atau gong kecil (kromong), sistem laras pentatonik lebih dari 2 oktaf. Ditambah dengan penyanyi laki-laki dan perempuan, dengan jumlah yang optimal (Yampolsky: 1990: 2).

Beberapa contoh bentuk syair lagu gambang kromong yang dinyanyikan dalam pesta pernikahan peranakan adalah mengikuti pola klasik yang dinyanyikan oleh penyanyi dalam bentuk pantun. Adapun beberapa syair lagu dalam bentuk pantunpantun tersebut dapat terlihat sebagai berikut.

Gunung Sinur pasirnya kuning
Tangguk udang airnya dalam
Bangun tidur kepala pusing
Habis begadang sehari semalam

Saya heran kereta api

Begitu panjang tidak kudanya

Saya heran si jantung hati

Kalau madang tidak sudahnya

Anak ikan beranak ikan

Ikan di laut panjang durinya

Sanak bukan beraya bukan

Kenapa baik manis budinya

(Yampolsky: 1990: 2).

\section{Penutup}

Berdasarkan paparan dan pembahasan terdahulu, dapat ditarik kesimpulan bahwa lahirnya musik bandar di Pesisir Nusantara cenderung dalam bentuk apropriasi musik. Bandar merupakan sebuah tempat berlabuhnya kapal, perahu, atau pelabuhan menjadi kota perdagangan diberbagai wilayah Pesisir di Nusantara. Proses munculnya musik bandar di berbagai Pesisir Nusantara, oleh karena dahulunya bandar adalah sebuah kota perdagangan (rempah, lada dan emas) yang diburu dan didatangi oleh berbagai bangsa di dunia. Tumbuh dan berkembangnya musik bandar keberadaannya diperankan oleh sekelompok orang (masyarakat) pribumi tempatan (lokal) melalui ajang kreatifitas baik secara langsung maupun tidak langsung yang dipengaruhi oleh sekelompok orang pendatang (Portugis, Belanda (Eropa), Arab, India dan China). Sebagaimana sebelumnya, ketibaan seni budaya yang dibawa oleh sekelompok orang pendatang tersebut, dijadikan sebagai ajang apresiasi oleh masyarakat pribumi. Peristiwa ini menjadi pendorong munculnya kreatifitas oleh sekelompok orang pribumi dalam bentuk apropriasi musikal sebagai perwujudan bentuk musik baru. Seiring perjalanan waktu, musik ini berkembang menjadi budaya masyarakat pesisir dengan menonjolkan seni musik tradisi 'kelokalannya' di berbagai bandar di Nusantara.

Secara musikal teramati bahwa jenis musik bandar memiliki satu jalur benang merah dari berbagai bentuk musik yang tumbuh dan berkembang sebagai seni budaya masyarakat Pesisir di Nusantara meliputi: musik gamat, musik ronggeng, musik ghazal, musik dondang sayang, musik keroncong dan musik gambang kromong. Dalam penyajiannya jenis musik ini sama-sama menggunakan alat gesek biola dalam sistem nada ditonis kecuali musik gambang kromong dengan menggunakan rebab. Kesamaan juga terjadi dalam konteks adanya pengaruh Portugis dan Belanda (Eropa), Arab, India dan China. Hal yang sama juga terlihat dalam bentuk dan struktur lagu yang disajikan, yaitu sama-sama memiliki intro, lagu pokok, interlud, dan coda. Pada setiap bagian kalimat lagu yang dinyanyikan, juga sama-sama memiliki sebuah counter melodi pengantar.

\section{Kepustakaan}

Alexander, Amanda dan Manisha Sharma. (2013). (Pre)determined Occupations: The PostColonial Hybridizing of Identity and Art Forms in Third World Spaces. The Journal of Social Theory in Art Education (33)(K.Staikidis, Ed.).86-104.

Ardipal. (2015). Peran Partisipan sebagai Bagian Infrastruktur di Sumatera Barat: Perkembangan Seni Musik Kreasi. RESITAL: JURNAL SENI PERTUNJUKAN, 16(1), 1524.

Arumsari, Chysanti. (2012). Keroncong Tugu: The Beat Nationalism from Betawi, Jakarta Indonesia. Prosiding The 4th International Conference on Indonesia Studies; "Unity, 
Diversity and Future" Jakarta: Ilmu Pengetahuan Budaya-Universitas Indonesia: 185-202.

Asnan, Gusti. (2007). Dunia Maritim Pantai Sumatera. Jogjakarta: Ombak.

Asri. (2015). Musik Melayu Ghazal Riau dalam Kajian Estetika. EKSPRESI SENI, 17(1), 103-114.

Franca, Antonio Pinto. (1985). Portuguese Influence in Indonesia. Jakarta: Calouste Gulbenkian Foundation.

Departemen Pendidikan Nasional. (2015). Kamus Besar Bahasa Indonesia Pusat Bahasa Edisi Keempat. Jakarta: PT Gramedia Pustaka Utama.

Departemen Pendidikan dan Kebudayaan. (1982). Sejarah Daerah Riau. Jakarta: Departemen Pendidikan dan Kebudayaan, Proyek Inventarisasi dan Dokumentasi Kebudayaan Daerah.

Destiana, Evie. (2012). Keroncong Stamboel Sebagai Bentuk Akulturasi Budaya Urban. JURNAL PEDAGOGIA, PENDIDIKAN, 1(2), 153-159.

Ganap, Victor. (2012). Konsep Multikultural dan Etnisitas Pribumi dalam Penelitian Seni. HUMANIORA, 24(2), 156-167.

Ganap, Victor, (2006). Pengaruh Portugis pada Musik Keroncong (Portuguese Influence to Kroncong Music). HARMONIA PENGETAHUAN DAN PEMIKIRAN SENI, $7(2)$.

Hajizar. (2001). Karakter Musikal Lagu-Lagu Melayu Deli dalam Rentak Senandung di Pesisir Timur Sumatera Utara. JURNAL PENELITIAN, 1(1), 27-37.

Hamid, Ismail. (1991). Masyarakat dan Budaya Melayu. Kuala Lumpur: Dewan Bahasa dan Pustaka Kementrian Pendidikan Malaysia.

Heins, Ernst. (1975). Keroncong and TanjidorTwo Cases of Urban Folk Music in Jakarta. Asian Music, 7(1), 21-22.

Martarosa. (2017). Musik Gamat: Apropriasi Musik Oleh Masyarakat Bandar Pesisir Sumatera Barat. [Disertasi] Program Studi Pengkajian Seni Pertunjukan dan Seni Rupa, Sekolah Pascasarjana Universitas Gadjah Mada.
Martarosa. (2016). Apropriasi Musikal dan Estetika Musik Gamat. RESITAL: JURNAL SENI PERTUNJUKAN, 17(1), 19-29.

Martarosa. (2008). Musik Gamat dari Pertunjukan Pentas ke Seni Pertunjukan Prosesi (Sebuah Tinjauan Historis. EKSPRESI SENI, 10(1), 26-44.

Mayall, Jeremy. (2016.) Cross-genre Hybridity in Composition: A Systematic Method Organised Sound, 21(1), 30-39

Musmal. (2010). Gambus Citra Budaya Bangsa. Yogyakarta: Media Kreativa.

Navis, A.A. (1984). Alam Terkembang Jadi Guru Adat dan Kebudayaan Minangkabau. Jakarta: PT Temprint.

Rokhani, Umilia, Aprinus Salam, dan Ida RochaniAdi. (2015). Konstruksi Identitas Tionghoa melalui Difusi Budaya Gambang Kromong: Studi Kasus Film Dikumenter Anak Naga Beranak Naga. RESITAL: JURNAL SENI PERTUNJUKAN, 16 (3), 141-152.

Sinar, Tengku Lukman. (1990). Pengantar Etnomusikologi dan Tarian Melayu. Medan: Perwira.

Soetomo. (2015). Pemberdayaan Masyarakat: Mungkinkah MunculAntitesisnya?. Yogyakarta: Pustaka Pelajar.

Suharto, Edi. (2014). Membangun Masyarakat Memberdayakan Rakyat: Kajian Strategis Pembangunan Kesejahteraan Sosial \& Pekerjaan Sosial. Bandung: Refika Aditama.

Sukotjo. (2012). Musik Gambang Kromong dalam Masyarakat Betawi Jakarta. ETNOMUSIKOLOGI INDONESIA. 1(1).

Takari, Muhammad dan Heristina Dewi. (2008). Budaya Musik dan Tari Melayu. Medan: USU Press.

Takari, Muhammad. (2006). Musik Melayu: Akar Budaya, Akulturasi, Perubahan, dan Kontinuitas." EKSPRESI SENI Jurnal Ilmu Pengetahuan dan Karya Seni, 8(2), 185-212. Usop, Ahmad. (2008). "Dondang Sayang Seni Tradisi Melaka." MEDIA DAN SENI WARISAN MELAYU SERUMPUN DALAM GENDANG NUSANTARA. Kuala Lumpur: Jabatan Pengkajian Media Universitas Malaya. Vickers, Adrian. Peradaban Pesisir Menuju Sejarah 
Budaya Asia Tenggara. Denpasar: Pustaka Larasan, Bekerja Sama dengan Udayana University Press.

Yampolsky, Phillip. (1990). Music of Indonesia 3 (Music from the Outskirts of Jakarta: Gambang Kromong”, Dokumentasi Teks dan Rekaman Audio CD (Tangerang, Jakarta Barat: Recorded, Smithsonian/Folkway cd/c, SF 40057.

\section{Webtografi}

Foto repro dari video: Persatuan Dondang Sayang Negeri Malaka, 21 Sep 2013). https://www. youtube.com/watch?v=huShYzkrLgw. Diakses pada tanggal16 April 2016.

Foto repro dari video: Grup Musik Ghazal "Dendang Serumpun” Pimpinan Bpk. Agus
Salim Tanjung Batu KEPRI, 2015) https:// www.youtube. com/watch?v $=\mathrm{dm} 338 \mathrm{qB} 96 \mathrm{PY}$. Diakses pada tanggal 16 April 2016.

(Foto: Grup "Keroncong Tugu” Jakarta, 2014). https://www.youtube.com/watch? $\mathrm{v}=\mathrm{qci}$ 3HE75NLs. Diakses pada tanggal 15 April 2016.

(Foto repro dari video: Group Sinar Betawi Entertainment, 2015). https://www. youtube. com/watch?v=Y-L9du9lguE. Diakses pada tanggal 15 April 2016.

Laman Resmi Jabatan Kebudayaan Kesenian Malaysia, http://www.jkkn.gov.my/ms/ghazal -0. Diakses pada tanggal 19 April 2016.

Rohaya, Siti. (2010). Musik Ghazal Johor. http:// ghazal-smp2252.blogspot.co.id/2010/09/ ghazal-johor.html. Diakses pada tanggal 15 April 2016. 